\title{
A Conceptual Tool for Sustainable Management of Rice Residue: Using Rice Straw-Based Formulations as Elicitors of Induced Resistance against Plant Pathogens
}

\author{
Soum Sanogo* \\ Department of Entomology, Plant Pathology, and Weed Science, New Mexico State University, USA
}

\begin{abstract}
The general focus of this letter is on the issue of rice straw management. The letter succinctly describes the challenges faced in the management of rice straw. Then, the letter makes a case for an innovative approach to managing rice straw by using rice straw for disease and pest control. Within this context, the letter pinpoints the biochemical characteristics of rice straw and the potential of exploiting these characteristics by using rice straw as a source of exogenous phenolic acids for eliciting induced resistance. This perspective is unique, and to the knowledge of the author, it has not been considered previously in the literature of rice straw management.
\end{abstract}

Rice (Oryza sativa L.) is one of the most economically important poaceous crops grown widely around the world. Cultivation of rice is accompanied by production of high amount of straw that is managed through a wide array of methods including incorporation in soil followed by microbial degradation during tillage or burning prior to tillage [1,2]. Alberto and Sanogo [3] reported that the practice of burning rice straw is laden with two negative environmental impacts. Smokes generated during burning operations may affect atmospheric quality beyond the burning area [4]. Additionally, soil microbial characteristics may be affected by burning and thereby nutrient cycling may be impeded.

Sustainable and environmental-friendly approaches are needed for managing rice straw residues. One approach is the utilization of rice straw for controlling plant pathogens and pests. Extensive research has shown that rice plants and rice straw have allelopathic properties, which affect negatively the biology of weeds resulting in inhibition of seed germination and weed growth. These characteristics can be exploited in terms of controlling weeds [5-8]. Alberto and Sanogo [3] showed that incorporation of rice straw in soil in conjunction with swine manure reduced incidence of Phytophthora fruit rot by 72 and $85 \%$ in tomato (Solanum lycopersicum L.) and eggplant (Solanum melongena L.), respectively and disease severity was reduced by $67 \%$ in tomato and $80 \%$ in eggplant. Mechanisms of disease reduction postulated by Alberto and Sanogo [3] included decreased dispersal of pathogenic inoculum and increased activities of antagonistic microorganisms. Other possible explanations could be the fungitoxicity of rice straw, as previous work has demonstrated the negative impacts of rice tissue extracts on the phenology of plant pathogens [8]. For example, rice root exudates were shown to exert inhibitory effects on spore germination and sporulation in Fusarium oxysporum f. sp. niveum, causal agent of Fusarium wilt in watermelon (Citrullus lanatus Thunb.) [6].

Rice straw has other biochemical characteristics that could be exploited in disease control through induced systemic resistance. Compounds found in rice straw include several phenolic acids such as salicylic acid, syringic acid, vanillic acid, and gallic acid $[7,9,10]$. The content of phenolic acids such as p-coumaric, ferulic, vanillic, syringic, and salicylic acids in rice straw was reported to vary between 0.002 and $0.037 \%$ on dry weight basis of straw materials [10]. Phenolic acids, such as those found in rice straw, have been shown to elicit induced systemic resistance in plants [11]. For example, in the pathosystem of barley (Hordeum vulgare L.)-powdery mildew (Blumeria graminis f. sp. hordei), when the first leaves were treated with $1 \mathrm{mM}$ vanillic acid, isovanillic acid, or syringic acid, infection of the second leaves by mildew was reduced by 81 to $87 \%$ [12]. War et al. [13] conducted a study on chickpea (Cicer arietinum L.) and concluded that salicylic acid, applied at a concentration of $1.5 \mathrm{mM}$ could be used to induce resistance to both biotic and abiotic stresses.

*Corresponding author: Soum Sanogo, Department of Entomology, Plant Pathology, and Weed Science, New Mexico State University, Las Cruces, NM 88003, USA

Accepted: November 20, 2018

Published online: November 22, 2018

Citation: Sanogo S (2018) A Conceptual Tool for Sustainable Management of Rice Residue: Using Rice Straw-Based Formulations as Elicitors of Induced Resistance against Plant Pathogens. J Rice Res Dev 1(1):59-60 
Citation: Sanogo S (2018) A Conceptual Tool for Sustainable Management of Rice Residue: Using Rice Straw-Based Formulations as Elicitors of Induced Resistance against Plant Pathogens. J Rice Res Dev 1(1):59-60

The benefit of induced resistance in crop protection has been widely demonstrated using various elicitors including botanical or plant extracts $[11,14,15]$. However, there is virtually no or little work on the potential of rice straw extracts as inducers of systemic resistance to plant pathogens. Rice straw extracts could be used as an exogenous source of phenolic acids for eliciting induced resistance. Using rice straw for inducing resistance is an innovative concept that can provide an environmentally-sound and sustainable approach to managing rice straw residue and plant pathogens. Research on this concept will entail several aspects including identification of predominant phenolic acids in straw of different rice varieties, methodologies of extract preparation, collection and application, and comparative studies on the efficiency of induced resistance following application of rice straw-based extracts versus application of commercial formulations used for activating induced resistance in plants.

\section{Compliance with Ethical Standards}

The author acknowledges compliance with ethical standards applicable to the Journal of Rice.

\section{Research and Developments}

\section{Funding}

The author acknowledges financial support from the New Mexico Ag. Experiment Station.

\section{Conflict of interest}

The author declares he has no conflict of interest.

\section{Use of human participants or animals}

The author declares that this article does not contain any studies with human participants or animals performed by the author.

\section{References}

1. Dobermann A, Fairhurst TH (2002) Rice straw management. Better Crops International 16: 7-11.

2. Taniguchi M, Suzuki H, Watanabe D, et al. (2005) Evaluation of pretreatment with Pleurotus ostreatus for enzymatic hydrolysis of rice straw. J Biosci Bioeng 100: 637-643.
3. Alberto RT, Sanogo S (2012) Reducing phytophthora fruit rot in eggplant and tomato fruits using rice straw and swine manure. Plant Pathology \& Quarantine 2: 153-160.

4. Nguyen BC, Mihalopoulos N, Putaud JP (1994) Rice straw burning in Southeast Asia as a source of $\mathrm{CO}$ and COS to the atmosphere. J Geophys Res-Atmos 99: 16435-16439.

5. Chung IM, Ahn JK, Yun SJ (2001) Identification of allelopathic compounds from rice (Oryza sativa L.) straw and their biological activity. Can J Plant Sci 81: 815-819.

6. Hao WY, Ren LX, Ran W, et al. (2010) Allelopathic effects of root exudates from watermelon and rice plants on Fusarium oxysporum f. sp. niveum. Plant Soil 336: 485-497.

7. Kato-Noguchi $\mathrm{H}$ (2008) Allelochemicals released from rice plants. Jpn J Plant Sci 2: 18-25.

8. Kong C, Xu X, Zhou B, et al. (2004) Two compounds from allelopathic rice accession and their inhibitory activity on weeds and fungal pathogens. Phytochemistry 65: 1123-1128.

9. Silverman $P$, Seskar M, Kanter D, et al. (1995) Salicylic acid in rice (biosynthesis, conjugation, and possible role). Plant Physiol 108: 633-639.

10. Kuwatsuka S, Shindo H (1973) Behavior of phenolic substances in the decaying process of plants: I. Identification and quantitative determination of phenolic acids in rice straw and its decayed product by gas chromatography. Soil Sci Plant Nutr 19: 219-227.

11. Kuć J (2001) Concepts and direction of induced systemic resistance in plants and its application. Eur J Plant Pathol 107: 7-12.

12. Walters DR, Mitchell AF, Hampson J, et al. (1993) The induction of systemic resistance in barley to powdery mildew infection using salicylates and various phenolic acids. Ann Appl Biol 122: 451-456.

13. War AR, Paulraj MG, War MY, et al. (2011) Role of salicylic acid in induction of plant defense system in chickpea (Cicer arietinum L.). Plant Signal Behav 6: 1787-1792.

14. Burketová L, Trdá L, Ott PG, et al. (2015) Bio-based resistance inducers for sustainable plant protection against pathogens. Biotechnol Adv 33: 994-1004.

15. Hammerschmidt R (1999) Induced disease resistance: how do induced plants stop pathogens? Physiol Mol Plant P 55: 77-84.

DOI: $10.36959 / 973 / 420$

Copyright: (C) 2018 Sanogo S, et al. This is an open-access article distributed under the terms of the Creative Commons Attribution License, which permits unrestricted use, distribution, and reproduction in any medium, provided the original author and source are credited. 